UDC 633.13:632.954

\title{
CONTROL OF WEED COMPONENT IN MAIZE CROPS WHEN APPLYING POSTEMERGENT HERBICIDES
}

\section{O. Gurmanchuk ${ }^{1}$, N. Plotnytska ${ }^{1}$, O. Nevmerzhytska ${ }^{1}$, I. Pavliuk ${ }^{1}$, T. Tymoshchuk ${ }^{1}$, L. Bondareva ${ }^{2}$}

Article info

Received

19.05.2020

Accepted

24.06.2020

\section{${ }^{1}$ Zhytomyr}

National

Agroecological

University

7, Staryi Blvd,

Zhytomyr, 10008, Ukraine

${ }^{2}$ National

University

of Life and

Environmental

Sciences

of Ukraine

15, Heroyiv

Oborony Str.,

Kyiv,

03041, Ukraine

E-mail: gurmanchuka@ gmail.com;

plotnat@ukr.net
Gurmanchuk, O., Plotnytska, N., Nevmerzhytska, O., Pavliuk, I., Tymoshchuk, T., Bondareva, L. (2020). Control of weed component in maize crops when applying postemergent herbicides. Scientific Horizons, 07 (92), 53-58. doi: 10.33249/26632144-2020-92-7-53-58.

Obtaining high and stable yields of corn is possible only under conditions of maintaining a cultivation technology as well as a complex system of protection against pests. This system is based on the protection of maize crops against weeds, as this crop is considered to be one of the weakest, competing with weeds, in agrophytocenosis. The peculiarities of maize crops protection against the most common types of weeds should be based on the knowledge of their species composition, taking into account the specific soil and climatic conditions of the crop cultivation.

The article investigates into the effectiveness of certain postemergent herbicides and their tank mixtures applied on maize crops and aimed at reducing the presence of weeds as well as improving the yield indices. The study was conducted on low-fertile sandy soils of Polissia. The presence and number of weeds in maize crops were monitored. It was ascertained that monocotyledonous weed species, namely Setaria pumila, Echinochloa crus-galli, and Elymus repens were slightly prevalent in the agrophytocenosis of maize. Dicotyledonous species were presented by Chenopodium album, Amaranthus, and Persicaria lapathifolian.

The separate application of herbicides Titus (water-soluble granules) and Prima (ssuspension emulsion) resulted in effectiveness of weed reduction at $56.1 \%$ and $47.5 \%$, respectively. The study of tank mixtures of analogous agents showed a notably higher efficiency. The highest index of technical efficiency amounted to $92.5 \%$ before the weed control was obtained in the experiment with the norms of the examined preparations $0.05 \mathrm{~kg} / \mathrm{ha}$ and $0.4 \mathrm{l} / \mathrm{ha}$. The yield indices in this variant were also the highest and amounted to $5.7 \mathrm{t} / \mathrm{ha}$, which is $3.0 \mathrm{t} / \mathrm{ha}$ more compared to the weed control. In case of manual weeding, the number of weeds was slightly higher compared to the better variant of the tank mixture under study. The yield index in this version of the experiment was $5.3 \mathrm{t} / \mathrm{ha}$.

Key words: maize, herbicide, weed, yield, tank mixture, agent, agrophytocenosis.

\section{КОНТРОЛЮВАННЯ БУР'ЯНОВОГО КОМПОНЕНТУ У ПОСІВАХ КУКУРУДЗИ ЗА ВИКОРИСТАННЯ СТРАХОВИХ ГЕРБІЦИДІВ}

\author{
О. В. Гурманчук ${ }^{1}$, Н. М. Плотницька ${ }^{1}$, О. М. Невмержицька ${ }^{1}$, \\ І. О. Павлюк ${ }^{1}$, Т. М. Тимощук ${ }^{1}$, Л. М. Бондарева ${ }^{2}$ \\ ${ }^{1}$ Житомирський національний агроекологічний університет \\ бульвар Старий, 7, Житомир, Україна, 10008 \\ ${ }^{2}$ Національний університет біоресурсів і природокористування України \\ вул. Героїв Оборони, 15, м. Київ, 03041, Україна
}

Отримання високих $і$ стабільних урожаӥв кукурудзи можливе лише за умови дотримання технології вирощування та комплексної системи захисту від шкідливих організмів. У ї̈ основу входить 
O. Gurmanchuk, N. Plotnytska, O. Nevmerzhytska, I. Pavliuk, T. Tymoshchuk, L. Bondareva захист посівів кукурудзи від бур'янів, оскільки ия культура відноситься до найбільш слабких за конкурениією з бур'янами у агрофітоценозах. Особливості захисту посівів кукурудзи від найбільш поширених видів бур'янів мають трунтуватися на знанні їх видового складу із обов'язковим врахуванням конкретних трунтово-кліматичних умов вирощування культури.

У статті досліджено ефективність використання окремих післясходових гербіџидів і їх бакових сумішей у посівах кукурудзи щодо зменшення присутності бур'янового компоненту $і$ покращення показників урожайності. Дослідження проведено на малородючих супіщзаних трунтах Полісся. Проведено моніторинг присутності та чисельності бур'янів у посівах кукурудзи. Встановлено, що в незначній мірі в агрофіточенозі кукурудзи переважали однодольні види бур'янів, зокрема мишій сизий, півняче просо, пирій повзучий. 3 дводольних видів найчастіше зустрічалися лобода біла, щчириця звичайна, гірчак шорсткий.

У результаті застосування гербіцидів Тітус, в.г. і Пріма, с.е. окремо, отримано ефективність зменшення бур'янового компоненту на рівні 56,1, і 47,5 \%, відповідно. При вивченні бакових сумішей аналогічних препаратів встановлено значно вищу їх ефективність. У варіанті досліду з нормами досліджуваних препаратів 0,05 кг/га і 0,4 л/га отримано найвищий показник технічної ефективності, що становив 92,5\% до забур'яненого контролю. Показники урожайності в иьому варіанті також були найвищими і становили 5,7 m/2а, що на 3,0 m/2а більще, порівняно із забур'яненим контролем. $У$ варіанті досліду з ручним прополюванням чисельність бур'янів була дещо більшою у порівнянні з кращим варіантом досліджуваної бакової суміші. Показник урожайності у иъьму варіанті досліду становив $5,3 \mathrm{~m} / 2$.

Ключові слова: кукурудза, гербічид, бур'ян, урожайність, бакова суміш, препарат, агрофітоценоз.

\section{Ветуп}

3-поміж усіх польових культур кукурудза є однією із найбільш рентабельних. За останнє десятиліття посівні площі кукурудзи в нашій країні зросли приблизно на $40 \%$ і становлять понад 4,5 млн га. Головною причиною збільшення площ посівів та зростання показників рентабельності iі вирощування $\epsilon$ висока урожайність. Протягом останніх десяти років середні показники урожайності кукурудзи в Україні зросли з 3,90 т/га до 5,37 т/га, хоча значна частина агропідприємств, які займаються вирощуванням цієї культури, отримують врожаї на рівні 100 і більше центнерів з одного гектара площі (Vozhegova \& Bielov, 2019; Zymaroieva, 2019).

Отримання високих і стабільних урожаїв кукурудзи можливе лише за умови дотримання технології вирощування та комплексної системи захисту від шкідливих організмів. У пі основу входить захист посівів кукурудзи від бур'янів, оскільки ця культура відноситься до найбільш слабких за конкуренцією 3 бур'янами у агрофітоценозах. Кукурудза пригнічує їх у десять разів гірше за пшеницю озиму i, у тричі слабше, ніж посіви соняшнику. Оскільки ця культура має невисокі темпи росту на перших етапах органогенезу і висівається широкорядно, у такому випадку 3'являється вільне місце для росту бур'янів, тобто - «вільна екологічна ніша», яка, 3 часом, заповнюється бур'янами. Втрати урожаю кукурудзи, за умов недостатнього регулювання чисельності бур'янового компоненту або за його відсутност, можуть сягати 30 і більше відсотків (Pashchenko et al., 2009; Taran et al., 2018; Kohan \& Gluschenko, 2019).

Присутність тих чи інших видів бур'янів у посівах кукурудзи обумовлена, в першу чергу, особливостями iї вирощування. Традиційно цю культуру вирощують широкорядним способом 3 міжряддями $70 \mathrm{~cm}$, хоча деякі господарства практикують інші схеми посадки, зокрема суцільні посіви тощо (Kalenska \& Taran, 2014; Bomba \& Bomba, 2019).

Щодо видового складу бур'янів у посівах кукурудзи, то він залежить від багатьох чинників, основними 3 яких $\epsilon$ умови i технологія вирощування культури. У посівах кукурудзи практично не зустрічаються зимуючі й озимі види бур'янів, тому що вони майже повністю знищуються при проведенні передпосівної культивації. Дуже рідко можна зустріти й ранні ярі види бур'янів, тому що посів кукурудзи здійснюють у прогрітий грунт, i час на їх проростання вичерпано. А тому видовий склад бур'янового компоненту агроценозу кукурудзи представлений переважно ярими види (Tsyikov, 2003; Vozhegova \& Bielov, 2019; Bomba \& Bomba, 
O. Gurmanchuk, N. Plotnytska, O. Nevmerzhytska, I. Pavliuk, T. Tymoshchuk, L. Bondareva

2019). Саме тому особливості захисту посівів кукурудзи від найбільш поширених видів бур'янів мають грунтуватися на знанні їх видового складу із обов'язковим врахуванням конкретних грунтово-кліматичних умов вирощування культури.

За сучасної інтенсивної технології вирощування кукурудзи хімічний метод захисту від шкідливих організмів, у т. ч. і від бур'янів, $\epsilon$ невід'ємним іiі елементом. Застосування гербіцидів на цій культурі $\epsilon$ найефективнішим заходом контролю забур'яненості посівів, особливо у гербокритичний період кукурудзи (Tsyikov, 2003).

Асортимент препаратів, шо представлені на ринку, для обмеження забур'яненості посівів кукурудзи є досить широким. 3-поміж грунтових гербіцидів найбільшого застосування набули препарати на основі діючих речовин таких як ацетохлор, пропізохлор, метолахлор та інші. Більшість досходових гербіцидів контролюють основні однорічні злакові і дводольні бур'яни. Дія на багаторічні види бур'янів у таких препаратів обмежена. Позитивною стороною застосування грунтових гербіцидів $\epsilon$ тривалий період їх захисної дії, який, за сприятливих погодних умов, може становити 30-50 діб, що створює оптимальні умови для росту кукурудзи на початкових етапах органогенезу. До недоліків застосування грунтових гербіцидів, зокрема на посівах кукурудзи, можна віднести сильні, тривалі опади, що здатні промивати діючі речовини препаратів у нижчі шари грунту або ж змивати їх із поверхні грунту, що значно знижує ix ефективність, або навпаки - сильна засуха, яка призупиняє їх дію на сходи бур'янів. Досходові гербіциди у більшості випадків застосовують великі компанії зі значними посівними площами цієї культури, що дає змогу краще розподілити зайнятість обприскувачів господарства (Kramarov et al., 2008; Pashchenko et al., 2009).

Післясходове застосування страхових гербіцидів на посівах кукурудзи має низку переваг перед грунтовими. До них можна віднести: вибір оптимального препарату або їх комбінації залежно від видового складу бур'янів; використання гербіцидів у оптимальні строки для знищення бур'янів і у допустимі для культури; здатність контролювати багаторічні як злакові, так і широколисті бур'яни; за умови недостатньої ефективності застосування грунтових гербіцидів, бур'яни можна знищити за допомогою страхових

\section{(Tsyikov, 2003; Kramarov et al., 2008).}

Важливою умовою застосування післясходових гербіцидів у посівах кукурудзи $є$ дотримання строків їх внесення, норми витрати препаратів, використання перевірених бакових сумішей або попередня перевірка на сумісність діючих речовин. Найбільш оптимальною фазою розвитку рослин кукурудзи для застосування страхових гербіцидів $\epsilon$ фаза 3-5 листків, допустимою, для деяких препаратів, вважається фаза від двох до восьми листків культури. Застосування гербіцидів у нерекомендовані терміни може призводити до зростання фітотоксичності препаратів (Kramarov et al., 2008). У зв'язку з цим, дослідження ефективності застосування гербіцидів та їх сумішей для регулювання рівня присутності бур'янового компонента у посівах кукурудзи є актуальним питання та потребує подальшого вивчення.

\section{Матеріали та методи досліджень}

Мета наших досліджень полягала у дослідженні ефективності страхових гербіцидів та їх сумішей в агроценозі кукурудзи в умовах Полісся України.

Польові дослідження проводили впродовж 2017-2019 pp. в умовах СФГ «Обрій» Лугинського району Житомирської області. Грунти господарства дерново-підзолисті, супіщані, характеризуються такими показниками: гумусу (за Тюріним і Кононовою) - 1,15-1,24 \%, азоту, що легко гідролізується (за Корнфілдом) 58-68 мг/кг грунту, рухомого фосфору (за Чириковим) - 109-171 мг/кг грунту, обмінного калію (за Чириковим) - 77-105 мг/кг грунту, $\mathrm{pH}_{\text {сол }}-5,8-6,3$. Технологія вирощування кукурудзи рекомендована для зони Полісся: лущення стерні після збору попередника (озима пшениця), осіння оранка на глибину 20-22 см, весняне закриття вологи, передпосівна культивація, посів. Для проведення досліджень висівали ранньостиглий гібрид кукурудзи фірми Pioneer П7709 з ФАО 190. Видовий склад бур'янового компоненту агроценозу кукурудзи визначали з використанням атласів та довідників (Veselovsky et al., 1988).

Схема досліду включала наступні варіанти: 1. Контроль забур'янений (обробка водою); 2. Контроль господарський (ручне прополювання); 3. Тітус, в.г. (д. р. римсульфурон - 250 г/кг) 0,05 кг/га; 4. Пріма, с.е. (д. р. флорасулам 6,25 г/л + 2-етилгексиловий ефір 2,4-Д 452,5 г/л), 0,5 л/га; 
5. Тітус, в.г., 0,04 кг/га + Пріма, с.е., 0,5 л/га; 6. Тітус, в.г., 0,05 кг/га + Пріма, с.е., 0,4 л/га. Гербіциди вносили у фазу 3-5 листків у культури за допомогою навісного обприскувача ОГН 600. Обліки забур'яненості посівів проводили тричі: перший - перед застосуванням гербіцидів; другий на 30 день після внесення; третій - перед збиранням урожаю. Розмір дослідної ділянки $200 \mathrm{~m}^{2}$. Повторність досліду триразова (Tribel, 2001). Математичну обробку отриманих результатів проводили методом дисперсійного аналізу згідно 3 методикою $\quad$ Б. О. Доспєхова (Dospehov, 1985).

\section{Результати досліджень та обговорення}

Дослідження щодо визначення видового та кількісного складу бур'янового компоненту агрофітоценозу кукурудзи проведено в умовах СФГ «Обрій» Лугинського району Житомирської області. Встановлено, що у посівах кукурудзи переважали однодольні види бур'янів, частка яких у загальній структурі забур'яненості становила $54,7 \%$.

В умовах проведення досліджень переважали такі види злакових бур'янів: мишій сизий (Setaria glauca L.), півняче просо (Echinochloa crus-galli L.), пирій повзучий (Elytrigia repens L.). Серед дводольних, домінуючими видами були: Chenopodium album L., Amaranthus retroflexus L. та Polygonum scabrum Moench (рис. 1).

Для отримання високих урожаїв кукурудзи на дерново-підзолистих супіщаних грунтах Полісся одним 3 ключових технологічних прийомів $\epsilon$ якісний контроль у iï посівах бур'янового компоненту. Оскільки, на дослідних ділянках були присутні злакові і дводольні бур'яни, що $є$ характерним для даного регіону в цілому, нами проведено дослідження щодо визначення ефективності страхових гербіцидів як ланки для комплексного вирішення проблеми забур'яненості. Встановлено, що початкова забур'яненість дослідних ділянок перед застосуванням досліджуваних препаратів була на рівні 49,3-52,4 шт./м² (табл. 1).

У результаті проведених досліджень встановлено, що за використання кожного 3 досліджуваних гербіцидів окремо, отримати високий рівень контролю забур'яненості у агрофітоценозі кукурудзи практично неможливо. Технічна ефективність застосування препарату Тітус, в.г. 3 нормою витрати 0,05 кг/га, становила $56,1 \%$, а препарату Пріма, с.е. 3 нормою витрати 0,5 л/га $-47,5 \%$

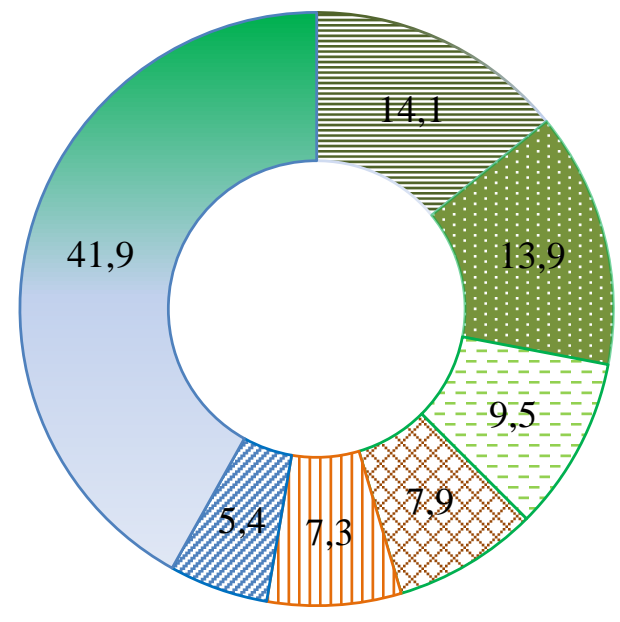

曰 Мишій сизий

뭄 Лобода біла

曰Півняче просо

曰Щириця звичайна

๑ Пирій повзучий

ఐ Гірчак шорсткий

๑нші види

\section{Рис. 1. Структура забур'яненості агрофітоценозу кукурудзи, середнє за 2017-2019 рр.}

Застосування сумішей препаратів сприяло зменшенню бур'янового компонента, а технічна ефективність їх застосування становила 89,6 та $92,5 \%$, що перевищує показники по інших варіантах досліду. Використання сумішей досліджуваних препаратів дозволило знизити чисельність бур'янів, порівняно із ручним прополюванням. Найкращим варіантом досліду $\epsilon$ застосування бакової суміші препаратів Тітус, в.г., 0,05 кг/га + Пріма, с.е., 0,4 л/га, що забезпечило зменшення початкової чисельності бур'янів 3 50,5 до 3,8 шт./M $\mathbf{M}^{2}$ на 30 добу після застосування препаратів. Перед збиранням урожаю кукурудзи у цьому варіанті досліду також було відмічено найменшу кількість бур'янів, що становила 7,7 шт./ $\mathrm{M}^{2}$. 
O. Gurmanchuk, N. Plotnytska, O. Nevmerzhytska, I. Pavliuk, T. Tymoshchuk, L. Bondareva

Таблиия 1. Вплив гербіцидів на забур'яненість посівів кукурудзи, середнє за 2017-2019 рр.

\begin{tabular}{|c|c|c|c|c|}
\hline \multirow[b]{2}{*}{ Варіант досліду } & \multicolumn{3}{|c|}{ Кількість бур'янів, шт./м² } & \multirow{2}{*}{$\begin{array}{c}\text { Технічна } \\
\text { ефективність, } \\
\%\end{array}$} \\
\hline & до обробки & $\begin{array}{l}\text { через } 30 \text { днів } \\
\text { після обробки }\end{array}$ & $\begin{array}{c}\text { перед } \\
\text { збиранням } \\
\text { врожаю }\end{array}$ & \\
\hline $\begin{array}{l}\text { Контроль забур'янений } \\
\text { (обробка водою) }\end{array}$ & 52,4 & 57,2 & 64,7 & - \\
\hline $\begin{array}{l}\text { Контроль господарський } \\
\text { (ручне прополювання) }\end{array}$ & 50,1 & 6,7 & 12,0 & 86,6 \\
\hline Тітус, в.г., 0,05 кг/га & 49,7 & 21,8 & 26,8 & 56,1 \\
\hline Пріма, с.е., 0,5 л /га & 52,0 & 27,3 & 30,1 & 47,5 \\
\hline $\begin{array}{l}\text { Tiтус, в.г., 0,04 кг/га + } \\
\text { Пріма, с.е., 0,5 л/га }\end{array}$ & 49,2 & 5,1 & 9,3 & 89,6 \\
\hline $\begin{array}{l}\text { Tiтус, в.г., } 0,05 \text { кг/га + } \\
\text { Пріма, с.е., 0,4 л/га }\end{array}$ & 50,5 & 3,8 & 7,7 & 92,5 \\
\hline $\mathrm{HIP}_{05}$ & 0,11 & 0,03 & 0,02 & - \\
\hline
\end{tabular}

Зменшення присутності бур'янового компоненту у посівах кукурудзи також позитивно позначилося і на показниках рівня урожайності культури (табл. 2). По усіх варіантах досліду було відмічено приріст урожаю, порівняно із варіантом без застосування препаратів. Нами також встановлено, що ручне прополювання посівів кукурудзи позитивно впливає не лише на зниження чисельності бур'янів, але й сприяє збереженню 2,6 т/га урожаю зерна кукурудзи, порівняно із забур'яненим контролем.

Табличя 2. Урожайність кукурудзи за застосування гербіцидів, середнє за 2017-2019 pр.

\begin{tabular}{|c|c|c|c|c|}
\hline \multirow[b]{2}{*}{ Варіант досліду } & \multirow{2}{*}{$\begin{array}{c}\text { Норма } \\
\text { витрати } \\
\text { препарату, } \\
\text { л/га, кг/га }\end{array}$} & \multirow[b]{2}{*}{$\begin{array}{c}\text { Урожайність, } \\
\text { т/га }\end{array}$} & \multicolumn{2}{|c|}{ Збережений урожай } \\
\hline & & & $\mathbf{T} / \mathbf{\Gamma a}$ & $\begin{array}{c}\% \text { до } \\
\text { забур'яненого } \\
\text { контролю }\end{array}$ \\
\hline $\begin{array}{l}\text { Контроль забур'янений } \\
\text { (обробка водою) }\end{array}$ & - & 2,7 & - & 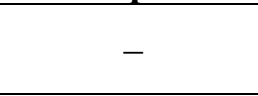 \\
\hline $\begin{array}{l}\text { Контроль господарський } \\
\text { (ручне прополювання) }\end{array}$ & - & 5,3 & 2,6 & 96,3 \\
\hline Тітус, в.г. & 0,05 & 4,6 & 1,9 & 70,4 \\
\hline Пріма, с.е. & 0,5 & 4,2 & 1,5 & 55,6 \\
\hline $\begin{array}{l}\text { Tiтус, в.г. }+ \\
\text { Пріма, с.е. }\end{array}$ & $0,04+0,5$ & 5,4 & 2,7 & 100,0 \\
\hline $\begin{array}{l}\text { Тiтус, в.г. + } \\
\text { Пріма, с.е. }\end{array}$ & $0,05+0,4$ & 5,7 & 3,0 & 111,1 \\
\hline $\mathrm{HIP}_{05}$ & - & 0,03 & 0,01 & - \\
\hline
\end{tabular}

При вивченні ефективності застосування гербіцидів у посівах кукурудзи нами встановлено, що обробка посівів препаратами Тітус, в.г. та Пріма, с.е. дозволяє отримати приріст урожаю зерна у межах 1,9-1,5 т/га, порівняно із забур'яненим контролем. Найвищу ефективність у зниженні чисельності бур'янового компоненту i, відповідно, збереження урожаю на рівні 2,7$3,0 \mathrm{~T} / г \mathrm{a}$, отримано у варіантах із використанням бакових сумішей. Застосування суміші гербіцидів Тітус, в.г., 0,05 кг/га + Пріма, с.е., 0,4 л/га сприяло максимальному збереженню урожаю зерна кукурудзи на рівні 3,0 т/га. 


\section{Висновки}

1. У структурі бур'янового компоненту агрофітоценозу кукурудзи в умовах Полісся України переважають злакові види бур'янів, частка яких становить $54,7 \%$.

2. Найвищий показник технічної ефективності у регулюванні чисельності бур'янів у посівах кукурудзи, що становить $92,5 \%$, отримано у варіанті із застосуванням бакової суміші препаратів Тітус, в.г., 0,05 кг/га + Пріма, c.e., 0,4 л/га.

3. Застосування у посівах кукурудзи гербіцидів та їх сумішей сприяє збільшенню урожайності зерна на 1,5-3,0 т/га, порівняно із забур'яненим контролем.

\section{References}

Bomba, M. Ya. \& Bomba, M. I. (2019). Buriany $\mathrm{v}$ ahrofitotsenozakh ta ekolohizatsiia zakhodiv shchodo kontroliuvannia yikh chyselnosti [Weeds in agrophytocenoses and greening measures to control their numbers]. Visnyk Umanskoho natsionalnoho universytetu, 1, 15-20. doi: 10.31395/2310-04782019-1-15-20 [in Ukrainian].

Dospehov, B. A. (1985). Metodika polevogo opyita (s osnovami statisticheskoy obrabotki rezultatov issledovaniy) [Methods of field experience (with basics of statistical processing of research results)]. Moskva : Agropromizdat [in Ukrainian].

Kalenska, S. M. \& Taran, V. A. (2014). Indeks urozhaynosti gibridiv kukurudzi zalezhno vid gustoti stoyannya roslin, norm dobriv ta pogodnih umov viroschuvannya [Yield index of maize hybrids depending on plant density, fertilizer rates and weather conditions]. Plant Varieties Studying and protection, 14 (4), 141-149. doi: 10.21498/25181017.13.2.2017.105395 [in Ukrainian].

Kohan, A. V. \& Gluschenko, L. D. (2019). Produktyvnist sortiv i hibrydiv kukurudzy za riznykh system udobrennia ta bezzminnoho yikh vyroshchuvannia [Productivity of corn varieties and hybrids under different fertilizer systems and their constant cultivation]. Visnyk ahrarnoi nauky, 10, 1823. doi: 10.31073/agrovisnyk201910-03 [in
Ukrainian].

Kramarov, S. M., Pisarenko, P. V. \& Shevchenko, M. S. (2008). Efektyvnist herbitsydiv v ahrotsenozakh kukurudzy [Efficacy of herbicides in corn agrocenoses]. Visnyk Poltavskoi derzhavnoi ahrarnoi akademii, 3, 5-12 [in Ukrainian].

Pashchenko, Yu. M., Borysov, V. M. \& Shyshkina, Yu. O. (2009). Adaptyvni i resursozberezhni tekhnolohii vyroshchuvannia hibrydiv kukurudzy [Adaptive and resource-saving technologies for growing corn hybrids]. Dnipro : Artpres [in Ukrainian].

Taran, V. H., Kalenska, S. M. \& Novytska, N. V. (2018). Stabilnist ta plastychnist hibrydiv kukurudzy zalezhno vid systemy udobrennia ta hustoty stoiannia roslyn v Pravoberezhnomu Lisostepu Ukrainy [Stability and plasticity of maize hybrids depending on fertilizer system and plant density in the Rightbank Forest Steppe of Ukraine]. Bioresursy $i$ pryrodokorystuvannia, 10 (3-4), 147-156. doi: 10.31548/bio2018.03.019 [in Ukrainian].

Trybel, S. O. (Ed). (2001). Metodyka vyprobuvannia i zastosuvannia pestytsydiv [Methods of testing and application of pesticides]. Kyiv : Svit [in Ukrainian].

Tsykov, V. S. (2003). Kukuruza: tekhnologiya. gibridy. semena [Maize: technology, hybrids, seeds]. Dnepropetrovsk: Zorya [in Russian].

Veselovsky, I. V., Lysenko, A. K. \& Manko, Yu. P. (1988). Atlas-vyznachnyk burianiv [Atlas is a determinant of weeds]. Kyiv : Urozhai [in Ukrainian].

Vozhehova, R. A. \& Bielov, Ya. V. (2019). Udoskonalennia tekhnolohii vyroshchuvannia hibrydiv kukurudzy v umovakh zroshennia Pivdnia Ukrainy [Improvement of technology of cultivation of corn hybrids in conditions of irrigation of the South of Ukraine]. Visnyk ahrarnoi nauky Prychornomoria, 2 (102), 41-48. doi:10.31521/2313-092X/20192(102) [in Ukrainian].

Zymaroieva, A. A. (2019). Prostorovo-chasovi zakonomirnosti variiuvannia urozhainosti kukurudzy $\mathrm{v}$ Ukraini [Spatio-temporal patterns of variation of corn yield in Ukraine]. Scientific Horizons, 2 (75), 58-66. doi: 10.33249/2663-2144-2019-75-2-58-66 [in Ukrainian]. 